UDC 311.175(635+637)-042.3(477)

JEL Classification: Q 12; C 15

\author{
T. V. KOBYLYNSKA, \\ $P h D$ (Economics), \\ Doctoral Student of Statistics Department, \\ Academy of Statistics, Accounting and Audit
}

\title{
Application of Cluster Analysis for Identifying Homogenous Zones of Operation of Agricultural Enterprises
}

The cluster analysis of agricultural enterprises is made by region of Ukraine. The analysis is made by the agricultural sector and its subsectors: plant-growing and animal husbandry. Homogenous regional zones characterizing the performance of agricultural enterprises are identified. The clustering is made using SPPS software. In the problems involved in the cluster analysis Euclidean distance is used. The cluster analysis is used for constructing green maps illustrating the impact of agricultural activities at enterprises on the production output of the agricultural sector and its subsectors: plant-growing and animal husbandry.

The constructed dendrogram was used for creating two clusters showing low and high performance of the plant-growing sector. The first cluster includes 17 regions of Ukraine have high performance along with low application of mineral fertilizers: Vinnytsya region, Dnipropetrovsk region, Donetsk region, Zhytomyr region, Zaporizhzhya region, Kyiv region, Kirovohrad region, Luhansk region, Mykolaiv region, Odesa region, Poltava region, Sumy region, Kharkiv region, Kherson region, Khmelnytsk region, Cherkasy region, and Chernihiv region. The second cluster includes 7 regions with low plant-growing performance along with intensive application of mineral fertilizers: Volyn region, Transkarpaty region, IvanoFrankivsk region, Lviv region, Rivne region, Ternopil region, Chernivtsi region.

The characteristics of regional zones by agricultural production output, numbers of cattle and poultry, and agriculture performance give evidence that in view of the similarity in the conditions of their territories, they require similar measures aiming to improve business environment in the sector and mechanisms for the development of agroindustrial complex in Ukraine.

Keywords: statistical analysis, agricultural enterprises, cluster analysis, plant-growing subsector, animal husbandry subsector, dendrogram, map, homogenous regional zones.

Introduction. The development of agricultural sector is subject of importance in the Action Program of the Cabinet of Ministers of Ukraine [1;2]. The government has elaborated priority areas of its implementation. The agricultural policy is designed to develop the sector at regional level; to enhance the socio-economic development in the regions; to delimitate lands in various forms of ownership, introduce the exclusively auction procedure for leasing of lands being in public or communal ownership, build the land leasing market (possibility to sell the rights and their mortgage); to simplify the procedure for registration of leasing contracts; to introduce the mechanisms for preservation and rehabilitation of land resources through melioration, re-cultivation, standard setting and standardization in the field of land protection; to grant the right for land disposal to consolidated territorial communities (or, otherwise, the obligatory negotiation of issues pertaining to land use with territorial communities). The abovementioned is supposed to boost the effectiveness of measures on government stimulation [1;2]. This raises the importance of statistical assessment of the current business environment in the regions and regional zoning.

Literature review. The national practice has no established approach to cluster analysis and statistical assessment of the agricultural output. Scientists have outlined some aspects of this problem as part of education disciplines or research interests. Methodological, organizational and practical issues related with constructing the components of agricultural statistics are contributed by Z. Baranik, S. Herasymenko, A. Holovach, V. Yeleiko, A. Yerina, H. Kulahina, R. Motoryn, O. Osaulenko, N. Parfentseva and others. It should be noted, however, that the published works cover only a part of the problems associated with the

T. V. Kobylynska, 2017

SCIENTIFIC BULLETIN OF THE NATIONAL ACADEMY
$3 \mathrm{i}$ OF STATISTICS, ACCOUNTING AND AUDIT, 2017, No 4


region, Dnipropetrovsk region, Kyiv region, Poltava region, Kharkiv region, and Cherkasy region (Figure 1,2).

The second cluster includes 8 regions: Zaporizhzhya region, Kirovohrad region, Mykolaiv region, Odesa region, Sumy region, Kherson region, Khmelnytsk region, and Chernihiv region.

The third cluster comprises the largest number of the regions with the lowest agricultural output (Volyn region, Donetsk region, Transkarpaty region, Ivano-Frankivsk region, Luhansk region, Lviv region, Rivne region, Ternopil region, and Chernivtsi region). The map of Ukraine with cluster distribution (Figure 2) is constructed on the basis of the dendrogram (Figure 1) using the infographic software.

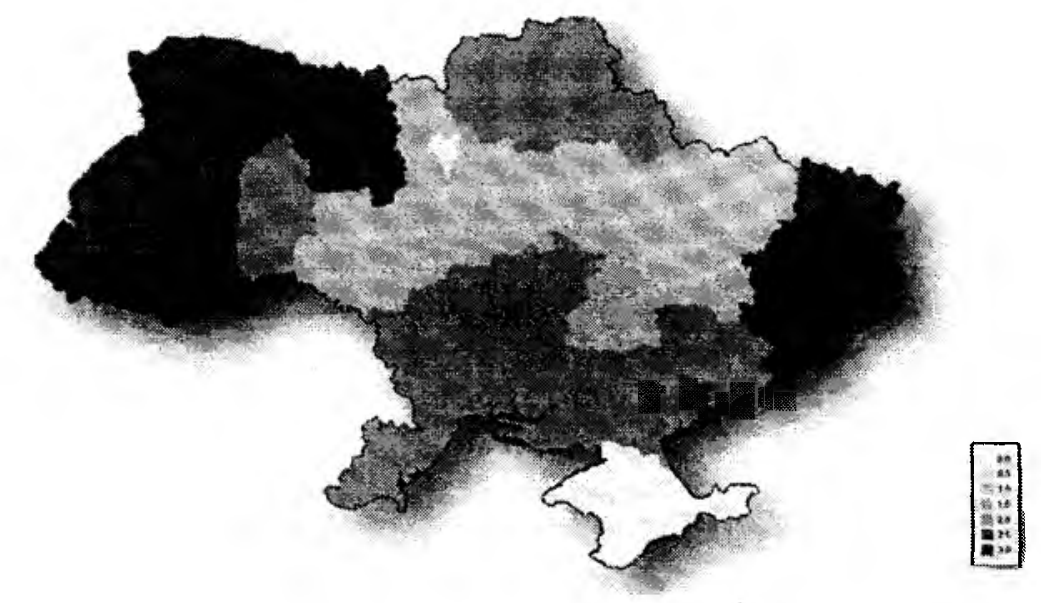

Fig. 2. The Map of the Regions' Distribution by Agricultural Output

Source: constructed by data of Fig. 1 .

The map shows that the regions are broken into three clusters (by agriculture performance indicators).

The cluster analysis of animal husbandry subsector is made by statistical indicators: number of cattle, thou. heads; number of pigs, thou. heads; number of poultry, thou. heads.

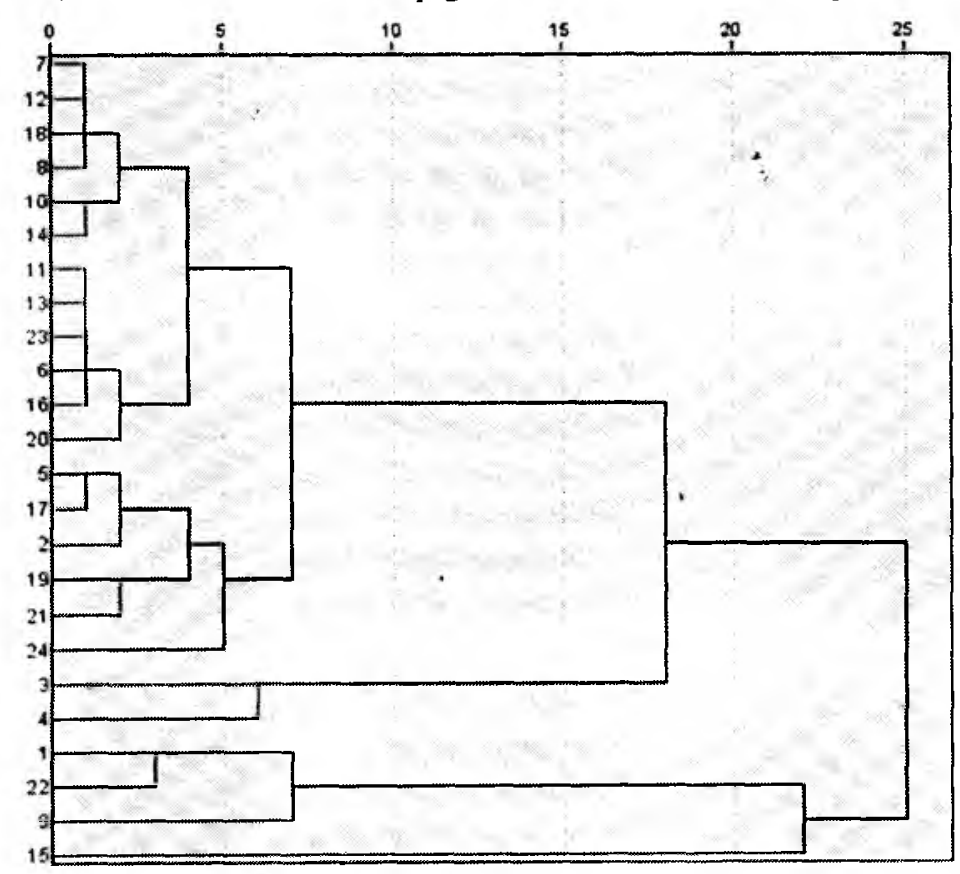

Fig. 3. The Dendrogram of Ukrainian Regions by Number, of Cattle and Poultry Source: constructed by data from [5] 


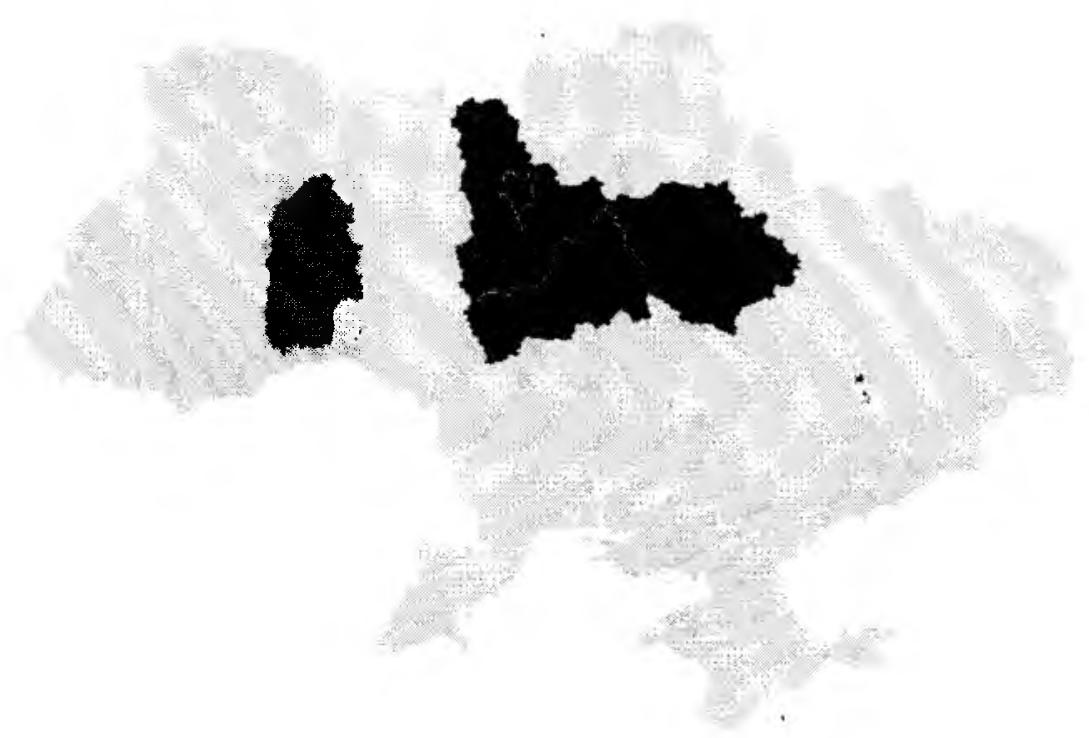

Fig. 4. The Map of Ukrainian Regions by Number of Cattle and Poultry

Source: constructed by data from Fig. 3 and [5]

The dendrogram (Figure 3 ) and the map (Figure 4) show two clusters formed by indicators of numbers of cattle and poultry. The first cluster includes the regions with the largest numbers of cattle and poultry (Vinnytsya region, Kyiv region, Poltava region, and Cherkasy region). The other ones are included in the second cluster.

The cluster analysis of the plant-growing subsector is made using the statistical indicators: cultivated areas, thou. ha; available tractors, units; mineral fertilizers applied per 1 ha of land; available grain combines, units. However, a problem with use of data in the cluster analysis exists, as no aggregate data are available on the plant-growing sector; the proposed indicators are, therefore, measured by incomparable scales.

Due to the incomparability of measurements units and the resulting impossibility of presenting the values of various indicators in one scale, the magnitude of intervals between the dots reflecting the objects' parameters in the space will be conditional on a scale, selected in a heuristic manner. In order to eliminate heterogeneity in measurement units of primary data, their standardization was made. They were normalized by being related to the values reffecting their characteristics.

Two clusters showing low and high levels of the plant-growing performance are constructed by use of the dendrogram (Figure 5).

17 Ukrainian regions have high plant-growing performance along with low application of mineral fertilizers: Vinnytsya region, Dnipropetrovsk region, Donetsk region, Zhytomyr region, Zaporizhzhya region, Kyiv region, Kirovohrad region, Luhansk region, Mykolaiv region, Odesa region, Poltava region, Sumy region, Kharkiv region, Kherson region, Khmelnytsk region, Cherkasy region, and Chernihiv region.

The second cluster includes 7 regions with low plant-growing performance along with intensive application of mineral fertilizers: Volyn region, Transkarpaty region, IvanoFrankivsk region, Lviv region, Rivne region, Ternopil region, Chernivtsi region. 


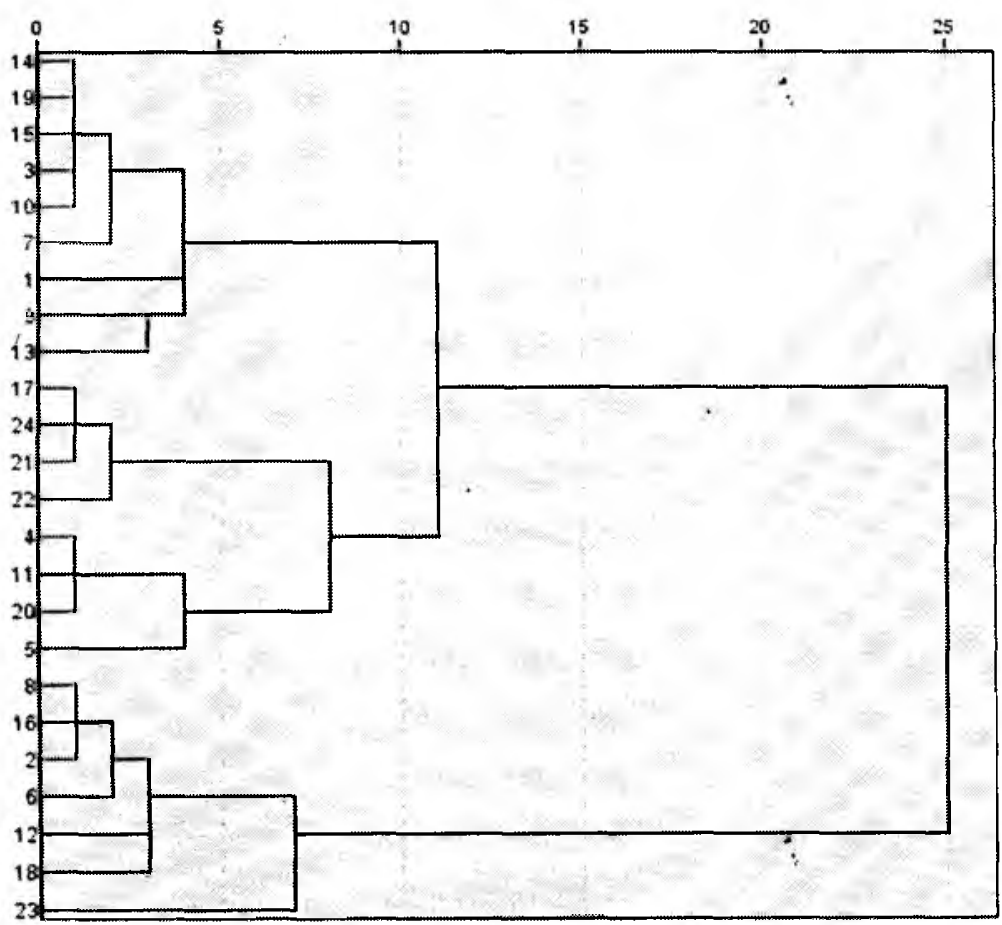

Fig. 5. The Dendrogram of Ukrainian Regions by Plant-Growing Performance Source: constructed by data from $[6 ; 7]$

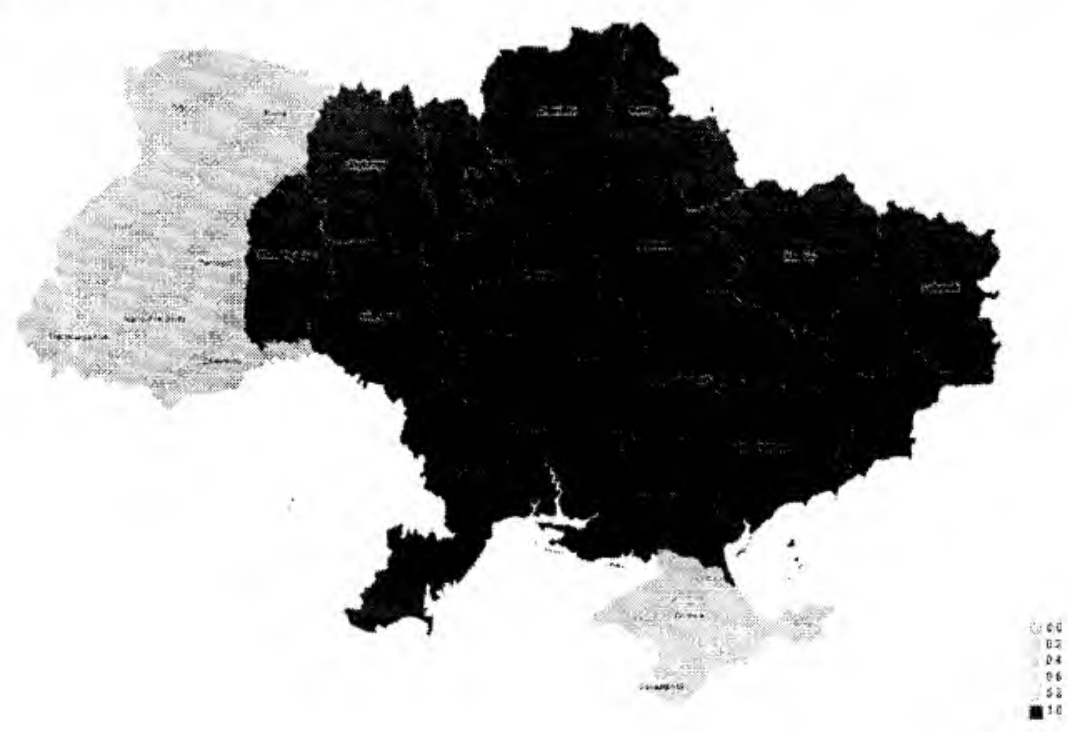

Fig. 6. The Map of Ukrainian Regions by Plant-Growing Performance

Source: constructed by data from [6;7] and Figure 5

The cluster analysis of the agricultural sector is made using the following indicators: production output, million hryvnya; number of cattle, thou. heads; number of pigs, thou. heads; number of poultry, thou. heads; cultivated areas, thou. ha; availability of tractors, units; mineral fertilizers applied per 1 ha of land, $\mathrm{kg}$; availability of grain combines, units.

Figure 7 shows homogenous regional zones of Ukraine by agricultural performance, identified by cluster analysis. The first cluster covers 17 regions where highly performing 
agricultural enterprises are located. The other regional zones are located in less favorable conditions for operation of the agricultural sector, compared with the first cluster.

The second cluster (Volyn region, Transkarpaty region, Ivano-Frankivsk region, Lviv region, Rivne region, Ternopil region, Chernivtsi region) covers mainly the regions with less favorable natural and climate conditions for agricultural activities.

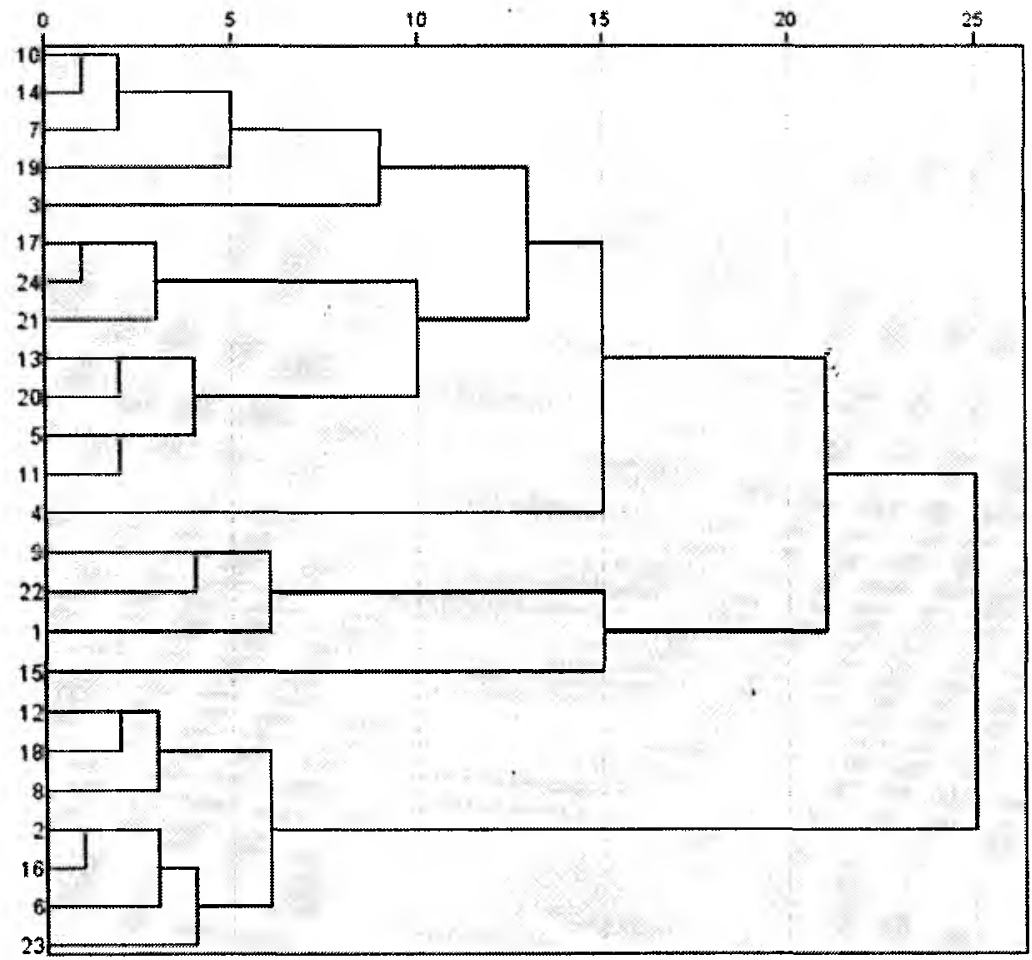

Fig. 7. The Dendrogram of Ukrainian Regions by Agriculture Performance Source: constructed by data [4-8]

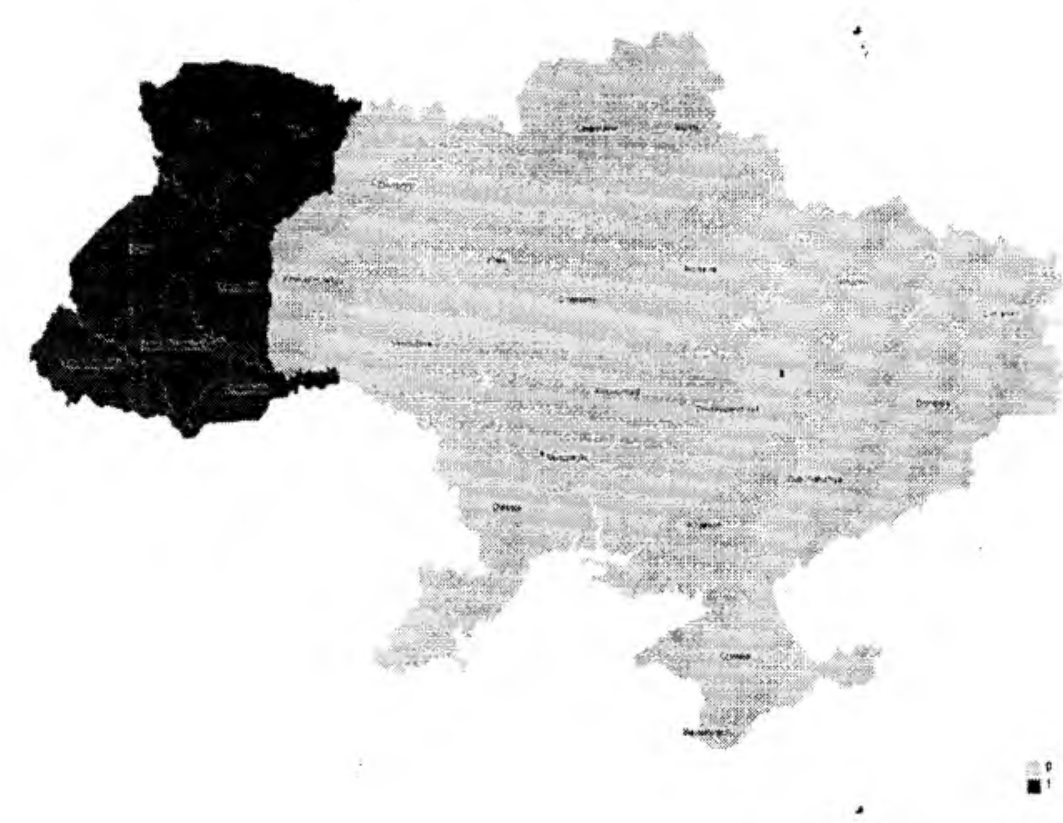

Fig. 8. The Map of Ukrainian Regions by Agriculture Performance Source: constructed by data [4-8] and Fig. 7 
The characteristics of regional zones by agricultural production output, numbers of cattle and poultry, and agriculture performance give evidence that in view of the similarity in the conditions of their territories, they require similar measures aiming to improve business environment in the sector and mechanisms for the development of agroindustrial complex in Ukraine.

Further studies with use of cluster analysis should be focused at constructing dendrograms and maps by category of polluted substances, and by amount of air pollution from stationary pollution sources, generated by the operation of agricultural enterprises. An important field of regional agricultural policies has to be analysis of ecological effects from the operation of agricultural enterprises.

\section{References}

1. Prohrama dialnosti Kabinetu Ministriv Ukrainy [Action program of the Cabinet of Ministers of Ukraine]. Retrieved from http://www.kmu.gov.ua. [in Ukrainian].

2. Stratehichni napryamy rozvytku silskoho hospodarstva na period do 2020 roku [Strategic areas of the development of agriculture for the period till 2020]. Yu. O. Lupenko, V. Ya. Mesel-Veselyak (eds.). Kyiv: NNTS "IAE", 2012 [in Ukrainian].

3. Duran, B. S. \& Odell, P. L. (1977). Klasternyi analiz [Cluster analysis]. Translated from English. Moscow: Statistika [in Russian].

4. Silske hospodarstvo Ukrainy [Agriculture in Ukraine]. 2015. Statistical yearbook. State Statistics Service of Ukraine. Retrieved from http://www.ukrstat.gov.ua/druk/publicat/ kat_u/publ7_u.htm [in Ukrainian].

5. Roslynnytstvo Ukrainy [Plant-growing in Ukraine]. 2015. Statistical yearbook. State Statistics Service of Ukraine. Retrieved from http://www.ukrstat.gov.ua/druk/publicat/ kat_u/publ7_u.htm [in Ukrainian].

6. Tvarynnytstvo Ukrainy [Animal husbandry in Ukraine]. 2015 Statistical yearbook. State Statistics Service of Ukraine. Retrieved from http://www.ukrstat.gov.ua/druk/publicat/ kat_u/publ7_u.htm [in Ukrainian].

7. Vnesennya mineralnykh ta orhanichnykh dobryv pid urozhay silskohospodarskykh kultur Ukrainy [Mineral and organic fertilizers applied in cultivated lands in Ukraine]. 2015. Statistical yearbook. State Statistics Service of Ukraine. Retrieved from http://www. ukrstat.gov.ua/druk/publicat/kat_u/publ7_u.htm [in Ukrainian].

8. Nayavnist silskohospodarskoi tekhniky ta enerhetychnykh potuzhnostey u silskomu hospodarstvi Ukrainy [Availability of agricultural machinery and energy capacities in the agriculture of Ukraine].

2015. Statistical yearbook. State Statistics Service of Ukraine. Retrieved from http:// www.ukrstat.gov.ua/druk/publicat/kat_u/publ7_u.htm .

T. В. КОБИЛИНСЬКА, кандидат економічних наук, докторант кафедри статистики,

Національна академія статистики, обліку та аудиту

\section{Застосування кластерного аналізу для виокремлення однорідних зон діяльності сільськогосподарських підприсмств}

Здійснено кластерний аналіз сільськогосподарських підприємсть за регіонами України. Кластерний аналіз проведено за галуззю сільського господарства загалом $i$ за його підгалузями - рослинництвом та тваринничтвом. Виокремлено однорідні регіональні зони, які характеризують ефективність діяльності сільськогосподарських підприємств. 3 метою розподілу регіонів Украйни на групи використано програму SPPS. У задачах кластерного аналізу використовувалась евклідова відстань. На основі кластерного аналізу побудовано зелені карти, які характеризують вплив сільськогосподарської діяльності підприєиств на виробництво продукцї сільського господарства та його підгалузей - рослинничтва та тваринничтва.

Ключові слова: статистичний аналіз, сільськогосподарські підприємства, кластерний аналіз, галузь рослинничтва, галузь тваринництва, дендрограма, картограма, однорідні регіональні зони. 


\section{T. В. КОБЫЛИНСКАЯ, \\ кандидат экономических наук, \\ докторант кафедры статистики, \\ Начиональная академия статистики, учета и аудита}

\section{Применение кластерного анализа для выделения однородных зон деятельности сельскохозяйственных предприятий}

Выполнен кластерный анализ сельскохозяйственных предприятий по регионам Украины. Кластерный анализ проведен по отрасли сельского хозяйства в челом и по его подотраслям - растениеводству и животноводству. Выделены однородные региональные зоны, характеризуюиие эфффективность деятельности сельскохозяйственных предприятий. С челью распределения регионов Украины по группам использована программа SPPS. В задачах кластерного анализа использовалось евклидово расстояние. На основе кластерного анализа построены зеленые карты, характеризуюице влияние сельскохозяйственной деятельности предприятий на производство продукции сельского хозяйства и его подотраслей-растениеводства и животноводства.

Ключевые слова: статистический анализ, сельскохозяйственные предприятия, жластерный анализ, отрасль растениеводства, отрасль животноводства, дендрограмма, картограмма, однородные региональные зоны.

Bibliographic description for quoting:

Kobylynska T. V. (2017). Application of Cluster Analysis for Identifying Homogenous Zones of Operation of Agricultural Enterprises. Scientific Bulletin of National Academy of Statistics, Accounting and Audit - Naukovyi visnyk Natsionalnoi akademii statystyky, obliku ta audytu, 4, 32-39 [in English]. 